\title{
ON DAMAGES INFLICTED UPON THE STALINGRAD SECTION OF THE LOWER VOLGA STEAMSHIP LINE IN THE GREAT PATRIOTIC WAR ${ }^{1}$
}

\author{
Olesya A. Gomanenko \\ Volgograd State University, Volgograd, Russian Federation
}

\begin{abstract}
Introduction. The paper reviews the Lower Volga shipping industry before the Great Patriotic War and after the Battle of Stalingrad. The goal is to establish the loss inflicted by the invaders upon the facilities of the Stalingrad section of the Lower Volga Steamship Line that suffered most from the hostilities. Methods and materials. The study is based on the objectivity principles and applies general scientific as well as specific historical methods. The paper is based on unpublished archival materials as well as on scientific publications on the Lower Volga Steamship Line. Analysis and results. The Lower Volga Steamship Line was created in 1934. It was a big economic entity. The territory of its operation stretched along the Volga from Kamyshin down to Lagan. The Steamship Line comprised two basic sections - the Stalingrad and Astrakhan ones. Before the Second World War the Steamship Line included five production establishments (ship repairing yards and workshops), 17 transit piers, a passenger river-boat station, two local piers with registered fleet, three crossings and other facilities. The Stalingrad section was the largest. Within its boundaries the principal Steamship Line unit was situated - the Stalingrad transit pier. 90 percent of it was destroyed in the Battle of Stalingrad. The Stalingrad section of the Steamship Line suffered most from the hostilities. The total amount of damage of the Steamship Line has been established.

Key words: Stalingrad, Second World War, Battle of Stalingrad, Volga, river transport, facilities, damage.

Citation. Gomanenko O.A. On Damages Inflicted upon the Stalingrad Section of the Lower Volga Steamship Line in the Great Patriotic War. Vestnik Volgogradskogo gosudarstvennogo universiteta. Seriya 4. Istoriya. Regionovedenie. Mezhdunarodnye otnosheniya [Science Journal of Volgograd State University. History. Area Studies. International Relations], 2021, vol. 26, no. 1, pp. 229-237. (in Russian). DOI: https://doi.org/10.15688/ jvolsu4.2021.1.20
\end{abstract}

УДК 94(47+57)“1938/1943”:658

ББК 63.3(2Р-4Вог)622,67

Дата поступления статьи: 27.09.2020

Дата принятия статьи: 11.11.2020

\section{К ВОПРОСУ О ПОСТРАДАВШИХ ОБЪЕКТАХ ХОЗЯЙСТВА СТАЛИНГРАДСКОГО УЧАСТКА НИЖНЕВОЛЖСКОГО РЕЧНОГО ПАРОХОДСТВА В ХОДЕ ВЕЛИКОЙ ОТЕЧЕСТВЕННОЙ ВОЙНЫ ${ }^{1}$}

\section{Олеся Александровна Гоманенко}

Волгоградский государственный университет, г. Волгоград, Российская Федерация 
пристань (порт), 90 \% которой было уничтожено в ходе сражения. Цель настоящей работы заключается в выяснении ущерба, нанесенного противником объектам Сталинградского участка пароходства, как наиболее пострадавшего от военных действий. Подробно рассматривается состояние портово-пристанского хозяйства до и после боевых действий. Таким образом, больше всего пострадал Сталинградский участок пароходства, который интенсивнее подвергался бомбардировкам. Береговое хозяйство Астраханского участка вовремя было эвакуировано, поэтому наибольшая часть его оборудования, механизации и материалов сохранилась. Установлен общий ущерб, причиненный объектам Нижневолжского речного пароходства в годы Великой Отечественной войны.

Ключевые слова: Сталинград, Вторая мировая война, Сталинградская битва, Волга, речной транспорт, объекты хозяйства, ущерб.

Цитирование. Гоманенко О. А. К вопросу о пострадавших объектах хозяйства сталинградского участка Нижневолжского речного пароходства в ходе Великой Отечественной войны // Вестник Волгоградского государственного университета. Серия 4, История. Регионоведение. Международные отношения. -2021. - Т. 26, № 1. - C. 229-237. - DOI: https://doi.org/10.15688/jvolsu4.2021.1.20

Введение. Нижневолжское речное пароходство (далее - НВРП) в 1930-1940-е гг. являлось одним из крупных хозяйствующих субъектов на Волге. Территориальные рамки НВРП с момента его образования в 1934 г. и до реорганизации в 1948 г. простирались от Камышина в верхнем течении реки и до Лагани в ее низовьях. Сюда входила и дельта Волги с выходом в Каспийское море. На протяжении второй половины 1930-х гг. происходило развитие речной инфраструктуры. Цель статьи выяснить урон, нанесенный противником объектам Сталинградского участка пароходства как наиболее пострадавшего от военных действий.

Методы и материалы. Настоящее исследование основывается на принципах объективности и историзма. В работе применялись общенаучные и специальные исторические методы (историко-сравнительный, историко-генетический, историко-системный). Статья базируется на неопубликованных документах федеральных и региональных архивов. Историографию составили труды по исследованию деятельности Нижневолжского речного пароходства накануне и в годы Великой Отечественной войны, в том числе вопросы по установлению ущерба речному хозяйству [7-9].

Анализ. В течение второй половины 1930-х гг. структура Нижневолжского речного пароходства менялась. Так, накануне Второй мировой войны в границах НВРП находилось два технических участка пути, которые перестали принадлежать пароходству, а подчинялись Бассейновому управлению пути.
Сталинградский участок пути располагался от Камышина до Черного Яра, Астраханский от Черного Яра до Астрахани соответственно. Технические участки водного пути обеспечивали должное содержание всего водного пути [12, л. 4 об., 62, 92].

Территориально с этими участками совпадали Сталинградский и Астраханский диспетчерские пункты НВРП по руководству движением флота. К ним относились и два замкнутых пункта пристаней - Красноармейск и Владимировка [6, л. 7 об.]. Накануне Великой Отечественной войны общее руководство работой флота от пристани Камское Устье (Татарская АССР) до Астрахани осуществлялось диспетчерами Управления НВРП. В 1941 г. Наркомат речного флота ввел новое положение, которое сохранялось на протяжении всей войны. Руководство движением флота стало осуществляться по более мелким участкам от Иловатки (на границе с Саратовской областью) до Астрахани.

Диспетчерское управление флотом производилось с помощью технических средств связи, которые в довоенный период были недостаточно развиты. В ходе Сталинградского сражения эта ситуация осложнилась. В результате бомбардировок и пожаров сгорел дом связи пароходства. Вместе с ним было уничтожено оборудование местной междугородней станции «Река» и телеграф. Помимо этого, пострадало 70 км столбовой линии электропередачи, длинноволновая радиостанция и др. Ущерб, нанесенный средствам связи НВРП, составил 1 млн руб. [18, л. 2 ; 21 , л. 78 об.]. 
В структуру пароходства входили промышленные предприятия, осуществлявшие капитальный, а также средний и текущий ремонт местного и транзитного флота. Новые суда промпредприятия НВРП не строили. На левом берегу Волги в Красной Слободе напротив г. Сталинграда располагался Сталинградский судоремонтный завод (далее CC3). Ниже по течению Волги на правом берегу реки находились Красноармейские судоремонтные мастерские, примыкавшие к одноименной пристани. В июле 1941 г. в Красноармейск эвакуировался Гомельский судостроительный судоремонтный завод. Через месяц на его базе и на месте мастерских был основан Красноармейский судостроительный судоремонтный завод (далее КСС3) $[10$, л. 8]. На правом берегу Волги в 170 км ниже Сталинграда во Владимировке располагались судоремонтные мастерские. В Астрахани работали судоремонтный завод им. Урицкого и ремонтные мастерские им. Сергеева [19, л. 21 об.-22].

С началом военных действий в Сталинграде производился демонтаж оборудования заводов и их отправка на другие промышленные предприятия страны. Так, завод им. Урицкого был эвакуирован в г. Гурьев (порт на Каспийском море, Казахская (СР) на Гурьевский судоремонтный завод [17, л. 1]. Часть оборудования Сталинградского судоремонтного завода также была перевезена в г. Гурьев. Часть мощностей СС3 в сентябре 1942 г. была отправлена за 10 км от Волги в колхоз им. Фрунзе. В декабре 1942 г. Сталинградский завод переехал в Булгаковский затон, который находился в 70 км от Сталинграда вниз по течению реки [22, л. 2].

В ходе Сталинградской битвы Сталинградскому судоремонтному заводу был нанесен урон в размере 4 млн рублей [14, л. 2 об.]. Полностью погиб жилой и служебный фонд, лесопильный цех и др. Частично были разрушены литейный и котельный цехи. Несмотря на разрушения, завод продолжал функционировать и во время боевых действий. Так, только за сентябрь 1942 г. было отремонтировано 8 воинских паромов и 11 речных судов. Не переставая работать в течение всей навигации, СС3 осуществил ремонт более 120 единиц. Свыше половины отремонтированного флота пришлось на период бомбардировки завода [2, с. 114-117].

Красноармейский судостроительный судоремонтный завод меньше пострадал от военных действий, чем ССЗ. Оборудование и кадры КССЗ в августе 1942 г. были эвакуированы на судоремонтный завод в г. Чистополь (Татарская АССР) [15, л. 43]. Не все заводы и мастерские демонтировались и вывозились. В результате боевых действий был нанесен значительный ущерб промышленным предприятиям НВРП.

К началу войны пароходству Нижней Волги принадлежало 17 транзитных пристаней. На самостоятельном балансе стоял пассажирский вокзал. Помимо этого, две пристани (Сталинградская и Астраханская) были с приписным к ним местным флотом. Все пристани делились по разрядам в соответствии с их грузооборотом. Перворазрядными пристанями являлись: Сталинград транзитная, Сталинград местного флота, Астрахань транзитная, Астрахань местного флота, Красноармейск, Владимировка. Ко второму разряду принадлежала пристань Камышин. К промежуточным транзитным пристаням третьего разряда относилось еще 12 причальных пунктов. НВРП принадлежали переправы через Волгу у пристаней Сталинград, Камышин и Дубовка. В Астрахани переправа находилась в ведении Астраханского Горсовета [12, л. 3 об.].

Небольшие пристани НВРП пострадали менее всего от военных действий, так как имели минимальное пристанское оборудование и удаленное местоположение. В основном на таких пристанях страдали дебаркадеры, выполнявшие причальную функцию, и суда, стоявшие на рейде. В результате бомбардировок и пожаров погибали инвентарь стоечного флота и грузы, располагавшиеся на нем. Так, на пристанях Енотаевск, Каменный Яр, Быковы Хутора, Замьяны часть дебаркадеров получили повреждения. На пристанях Даниловка, Никольское, Черный Яр и др. сгорело все причальное оборудование [8, с. 62-63].

Более крупные пристани пострадали больше. В частности, на пристани Камышин повреждены были первый (железнодорожный) и второй участки. В целом Камышинское береговое пристанское хозяйство не было раз- 
рушено. Владимировской пристани был нанесен ущерб более чем на 3 млн рублей. В результате военных действий сгорели пассажирский вокзал, грузовой склад и другие береговые объекты. Кроме того, частично были разрушены судоремонтные мастерские во Владимировке [4, л. $39 ; 18$, л. 2].

В целом Астраханский участок НВРП не так сильно пострадал от боевых действий, как Сталинградский. Астраханская транзитная (порт) и местная пристани понесли ущерб значительно меньший, чем Сталинградский порт и местная пристань. Наибольшая часть оборудования, механизированных установок и различных материалов Астраханских пристаней сохранилась. Береговое хозяйство успели демонтировать и эвакуировать в г. Гурьев.

Сталинградская транзитная пристань (Сталинградский порт) являлась самым крупным и главным пунктом Нижневолжского пароходства. Протяженность пристани, располагавшейся на правом берегу Волги, составляла 5,2 км от Лесотаски Горлесозаводов до хлебосоляного участка. Длинная береговая полоса в ширину доходила до 600 м (подход к причалам) [12, л. 3, 7, 25].

Сталинградский порт объединил в себе три основные функции. Во-первых, он являлся угольной базой для снабжения судов топливом. Во-вторых, сама пристань располагалась на трехэтажном деревянном дебаркадеpe № 120, который служил транзитным вокзалом и обслуживал пассажиров. В-третьих, порт обладал большим водным пространством для рейдового флота. Пристань осуществляла пассажирские и грузовые водные и смешанные (перевалка грузов с железной дороги на реку и обратно) перевозки. Ко всем грузовым причалам порта подходили железнодорожные пути. К двум городским участкам пристани были проложены вымощенные булыжником шоссейные дороги, требовавшие ремонта. Тяжеловесный причал, участок № 5 и Угольная база Сталинградского порта имели грунтовые подъезды, с которых производилась перевалка грузов смешанных перевозок. Пристань обслуживала две большие железнодорожные станции - Соляную и Волжскую [12, л. 7-7 об.].

Водная и общая береговая площадь Сталинградской транзитной пристани насчитыва- ла по 3 000,0 тыс. м² соответственно. Порт располагался в центре г. Сталинграда, что ограничивало его территорию. С одной стороны пристань соприкасалась с городскими постройками, с другой - крутым берегом Волги. На территории порта располагались пять производственных участков, где осуществлялись погрузочно-разгрузочные операции и хранение грузов. На всех участках находились склады для хранения грузов (лабазы). Их не хватало, а имевшиеся (в основном деревянные) нуждались в существенной модернизации. Накануне Великой Отечественной войны грузооборот транзитной пристани составлял 7 000,0 тыс. тонн в год [12, л. 7].

Каждый производственный участок Сталинградского порта имел свою специализацию. Так, участок № 1 (хлебосоляной) и № 5 (лесной) главным образом предназначались для переработки грузов малой скорости (нескоропортящиеся). Участки № 2 (городской), № 3 (городской) и № 4 (волгодонский) специализировались в основном на грузах большой скорости (требующих быстрой доставки). При этом второй и третий участки осуществляли перевалку грузов с железнодорожных вагонов на суда и наоборот вне зависимости от назначения груза (большой или малой скорости).

Первый участок имел три механизированных причала. На них производилась перевалка сыпучих грузов (соль, хлеб, химикаты) с реки на железную дорогу и обратно. Из Владимировки и Баскунчака прибывала соль. Остальные грузы поступали с верховьев Волги и Камы [11, л. 1 об., 4].

На втором участке располагались два механизированных причала для погрузочноразгрузочных операций штучных грузов. Участок принимал поступавшую продукцию в Сталинград с верхнего течения Волги. Далее грузы отправлялись в низовье реки. Прием грузов, следовавших с низовьев в верховья Волги, осуществлял третий участок [12, л. 10,11 об.].

Четвертый участок находился на мощеном камнем откосе и имел три механизированных причала для перевалки штучных грузов с железной дороги на реку и обратно. На причалах перерабатывались металлы и различные металлические изделия, а также грузы, находившиеся в мешках и ящиках, маши- 
ны, станки и другие штучные грузы весом до 2 тонн [12, л. 3].

На пятом участке, имевшем четыре механизированных причала, происходила перевалка леса с судов в вагоны. Участок находился рядом с тяжеловесным причалом и Угольной базой. Последняя использовалась для бункеровки топливом всего транзитного и местного волжского флота (в том числе технического). Угольная база имела ручные и механизированные причалы для переработки угля (из Донбасса), поступавшего по железной дороге [12, л. 18 об., 19].

Часть причальных пунктов г. Сталинграда принадлежала промышленным предприятиям и хозяйственным организациям (клиентуре). Такие причалы обслуживали только эти объекты. К ним относились крупные промышленные Сталинградские заводы: тракторный, «Баррикады», «Красный Октябрь», № 91, шпалопропиточный. Помимо этого, лесопромышленные организации и предприятия Народного комиссариата путей сообщения (далее НКПС) также имели причальные пункты. Свои причалы были и у клиентуры (Заготзерно, Главсоль, Облрыбтрест, Консервный завод, Торгплодоовощ и Гастроном) [3, л. 3, 57].

Причалы в основном представляли собой деревянные эстакады и временные мостики. Исключение составляли капитально сооруженные причалы НКПС, волгодонского участка и Красноармейского затона. Многие расположенные на причалах полувековые дебаркадеры требовали ремонта или замены [6, л. 3 об., 4].

Накануне войны пароходство Нижней Волги имело 34 грузовых причала большой и малой скорости. Кроме этого, на балансе стояло семь плавучих и 18 береговых полупортальных и железнодорожных кранов, более 3,0 тыс. м транспортеров и около 32,0 тыс. м² крытых складов. Всего насчитывалось 57 единиц различных механизмов [5, л. 8 об.; 13 , л. 18]. В частности, в Сталинградском порту находилось 15 грузовых причалов большой и малой скорости, 15 береговых и пять плавучих кранов, более 1,1 тыс. м транспортерной линии и 7,3 тыс. м² крытых складов. Различный ремонт механизмов (в том числе перегрузочных) и инвентаря на участках транзитной пристани осуществлялся в центральной механической мастерской на Сталинградском судоремонтном заводе. Материально-техническая база НВРП нуждалась в мощной реконструкции, однако ее слабый рост был фактически приостановлен с началом Второй мировой войны.

В пределах порта располагались торговая сеть и предприятия общественного питания Сталинградского отделения нижневолжской конторы «Торгводтранс». Так, на транзитном вокзале находились магазин, хлебо-бакалейная лавка, бакалейный и овощной ларьки, плавучая хлебо-бакалейная база (магазин № 6), павильон с прохладительными напитками, три плавучих лавки с промышленными и продуктовыми товарами. На территории порта располагались два плавучих ресторана и столовая № 2 с пропускной способностью 2800 чел. в сутки [12, л. 33-33 об.].

С началом боевых действий в Сталинграде некоторое оборудование портово-пристанского хозяйства НВРП было эвакуировано. Однако значительная часть погибла в результате бомбардировок противника и пожаров. Так, в начале августа 1942 г. в Куйбышев, Ульяновск и другие регионы эвакуировались материальные ценности склада Сталинградского порта на общую стоимость около 139,0 тыс. рублей. Кроме того, было демонтировано и отправлено вверх по Волге механизированное оборудование хлебного и соляного причалов. Однако по пути следования баржа с портовыми механизмами была разбомблена. В течение 23-25 августа на Сталинградской транзитной пристани сгорели все портовые сооружения, в том числе механизированное оборудование, погрузочно-разгрузочный инвентарь. Служебные помещения и жилищные постройки были разрушены. При пожаре погибло до 90 \% имущества порта. Уничтожено было 18 причалов с 15 дебаркадерами, 14 груженых складов, погибло и повреждено 18 кранов, 1,5 тыс. м береговых стационарных транспортеров, а также 57 жилых построек и другое оборудование, инвентарь [23, л. 135-135 об.]. Сталинградский порт потерял имущество на 18 млн руб. [20, л. 29].

Между вторым хлебосоляным и третьим городским участками порта располагалась территория пристани Сталинградского местного флота протяженностью 500 м с пасса- 
жирским вокзалом. В качестве причала использовался дебаркадер для Городской переправы. Местная пристань Сталинграда имела один грузовой участок, к которому были проложены железнодорожные пути, обеспечивавшие перевалку грузов с железнодорожных вагонов на суда и обратно. К причалам подходили грунтовые подъездные пути. Местный флот перевозил, соответственно, грузы местного значения [12, л. 37].

Сталинградская местная пристань обслуживала 12 линейных пристаней, которые располагались вверх по Волге от Сталинграда до Камышина (Красный Октябрь, Тракторный, Рынок и др.) и пять внизу по течению до Солодников (Светлый Яр, Райгород и др.). Пять причальных пунктов находилось на реке Ахтубе. Помимо этого, четыре пристани (Городская переправа Сталинград - Красная Слобода, Культбаза, Бакалда, Тумак) относились к пригородному сообщению. Причальное оборудование этих линейных пристаней составляли лишь дебаркадеры, которых и до войны не хватало [6, л. 4].

В ходе Сталинградской битвы все пристанское оборудование местной пристани Сталинград погибло. Ущерб составил 1,5 млн рублей. В частности, сгорел пассажирский вокзал (дебаркадер № 108), грузовой дебаркадер № 150, склады горючего и лесных материалов и др. Документация и инвентарь Управления местной пристани также были уничтожены [8, с. 61].

В первых числах августа 1942 г. часть пристанского оборудования Красноармейска была демонтирована и отправлена в г. Камбарку (Удмуртская АССР). В результате бомбардировок $75 \%$ хозяйства пристани было уничтожено. Урон составил 3 млн рублей. В пожаре сгорели служебные и жилые постройки. Менее всего пострадали лишь деревянные эстакады транспортерных линий [15, л. 43 ; 23, л. 115].

Результаты. Помимо береговых объектов, пострадало огромное количество флота НВРП. Значительная часть судов (около $25 \%$ п) погибла [9, с. 293-321]. Ущерб, нанесенный подвижному составу Нижней Волги, превысил 60 млн руб. [16, л. 16]. Свыше 73 млн руб. составил урон остальному имуществу пароходства, включая служебные, жи- лые, хозяйственные постройки, оборудование и др. [1, л. 109-112]. Общий ущерб, причиненный противником всему хозяйству Нижневолжского пароходства за годы Великой Отечественной войны, по разным сведениям доходил до 114 млн руб. [7, с. 120]. Больше всего пострадал Сталинградский участок НВРП. Именно на его объекты хозяйства пришелся разрушительный удар военных действий.

\section{ПРИМЕЧАНИЕ}

${ }^{1}$ Исследование выполнено при финансовой поддержке Минобрнауки России в рамках научного проекта № 0633-2020-0004 «Развитие методики виртуальной 3D реконструкции исторических объектов».

The study was financially supported by the Ministry of Science and Higher Education of the Russian Federation as research project no. 0633-20200004 "Development of methods of virtual 3D reconstruction of historical objects".

\section{СПИСОК ЛИТЕРАТУРЫ}

1. Акты о причиненном немецко-фашистскими захватчиками ущербе предприятиям НКРФ СССР. 1944 г. // Российский государственный архив экономики (далее - РГАЭ). - Ф. 9469. Оп. 1. - Д. 488.

2. Волгари в боях за Сталинград / А. А. Кантор, А. Т. Тажуризин (сост.). - Сталинград : Сталинградское книжное издательство, 1961. - 186 с.

3. Генеральная схема Гипроречтранса НКРФ о развитии Сталинградского речного порта (записки и чертежи). 1944 г. // Государственный архив Волгоградской области (далее - ГАВО). - Ф. 557. Оп. 19. - Д. 10.

4. Годовой отчет об эксплуатационной деятельности НВРП за 1943 г. // РГАЭ. - Ф. 9469. Оп. 6. - Д. 47.

5. Годовой отчет об эксплуатационной деятельности НВРП за 1945 г. // РГАЭ. - Ф. 9469. Оп. 6. - Д. 98.

6. Годовой отчет УНВРП за 1940 г. // РГАЭ. Ф. 1562. - Оп. 11. - Д. 1025.

7. Гоманенко, О. А. Навигация 1943 года: битва за Волгу продолжается / О. А. Гоманенко // Вестник Волгоградского государственного университета. Серия 4, История. Регионоведение. Международные отношения. - 2019. - Т. 24, № 3. - С. 115-125.

8. Гоманенко, О. Нижневолжское речное пароходство в Великой Отечественной войне. 1940- 
1945 гг. / О. Гоманенко. - Saarbrücken : LAP LAMBERT Academic Publishing, 2011. - 256 c.

9. Гоманенко, О. А. Новые данные о потерях речного флота в ходе Сталинградской битвы / О. А. Гоманенко // Стрежень : науч. ежегодник. - Вып. 3. Волгоград : Изд-во ВолГУ, 2003.-С. 293-321.

10. Доклад директора Красноармейского судостроительного и судоремонтного завода г. Сталинграда. 1942 г. //ГАВО. -Ф. 5513.-Оп. 2.-Д. 3. -Л. 7-15.

11. Контрольные цифры работы НВРП на 1937 г. // Государственный архив Астраханской области (далее - ГААО). - Ф. 2345. - Оп. 1. - Д. 232.

12. Краткое описание НВРП и Сталинградского речного порта за 1940 г. // ГАВО. - Ф. 557. Оп. 19. - Д. 1.

13. Материал для секретаря ОК ВКП(б) т. А.С.Чуянова, председателя Исполкома Сталинградского облсовета депутатов трудящихся т. И.Ф. Зименкова, секретаря ГК ВКП(б) т. И.А. Пиксина от Уполномоченного Госплана при СНК СССР по Сталинградской области т. Короткова «Об итогах восстановления г. Сталинграда за два года (апрель 1943 г. - апрель 1945 г.)» // ГАВО. - Ф. Р-686. - Оп. 20. - Д. 56.

14. Протокол № 24 закрытого партсобрания парторганизации Сталинградского судоремонтного завода «Об итогах навигации 1942 г.». 19 декабря 1942 г. // Центр документации новейшей истории Волгоградской области (далее - ЦДНИВО). Ф. 113. - Оп. 14. - Д. 165.

15. Сведения для зам. председателя СНК т. М.3. Сабурова от зам. председателя Госплана т. Зеленовского об эвакуации Красноармейского судоремонтного завода. 17 сентября 1942 г. // РГАЭ. - Ф. 4372. - Оп. 42. - Д. 847.

16. Сводный отчет по учету ущерба, причиненного немецко-фашистскими захватчиками и их сообщниками, хозяйству НКРФ СССР. 1944 г. // Государственный архив Российской Федерации (далее ГАРФ). - Ф. 7021. - Оп. 2. - Д. 356.

17. Список начальника технического отдела НКРФ т. Леонтьева с перечнем эвакуированных предприятий НКРФ. 3 мая 1943 г. // РГАЭ. - Ф. 4372. Оп. 43. - Д. 775.

18. Справка начальника НВРП т. Коченина «О восстановлении и подготовки к навигации 1943 г. хозяйства НВРП». 2 февраля 1943 г. // ЦДНИВО. Ф. 11418. - Оп. 1. - Д. 31.

19. Справка о современном состоянии Астраханского речного порта. 1938 г. // ГААО. - Ф. 2348. Оп. 1. - Д. 99.

20. Справка секретарю Сталинградского ГК ВКП(б) т. И.А. Пиксину от начальника Сталинградского речного порта т. Матурина «О подготовке к навигации 1943 г. и восстановлении хозяйства Сталинградского речного порта». 29 марта 1943 г. // ЦДНИВО. - Ф. 71. - Оп. 2. - Д. 125. - Л. 29.
21. Справка секретарю Сталинградского ОК ВКП(б) т. А.С. Чуянову от секретаря ОК ВКП(б) по транспорту т. И. Сидорова «О степени разрушения железнодорожного и водного транспорта и мероприятиях по восстановлению». Сентябрь 1943 г. // ЦДНИВО. - Ф. 71. - Оп. 2. - Д. 76.

22. Справка Уполномоченному комиссии партийного контроля при ЦК ВКП(б) по Сталинградской области т. И.А. Ягодкину от начальника НВРП т. Коченина и начальника политотдела НВРП т. Ширманова «О работе НВРП в условиях фронта в 1942 г.». 7 февраля 1943 г. // ЦДНИВО. - Ф. 11418. Оп. 1. - Д. 27.

23. Справки отдела и секретарей парторганизаций, начальников речного порта и железной дороги о восстановлении и работе железнодорожного и речного транспорта, о состоянии партийно-политической работы. Февраль - август 1943 г. // ЦДНИВО. -Ф. 71. - Оп. 2. - Д. 125.

\section{REFERENCES}

1. Akty o prichinennom nemecko-fashistskimi zahvatchikami ushherbe predprijatijam NKRF SSSR. 1944 g. [Acts on the Damage Inflicted by the Nazi Occupants upon the People's Commissariat for River Fleet Facilities. 1944]. Rossiyskiy gosudarstvennyy arkhiv ekonomiki (dalee - RGAE) [Russian State Archive of Economy], f. 9469, inv. 1, d. 488.

2. Kantor A.A., Tazhurizin A.T., eds. Volgariv bojah za Stalingrad [Volgari in the Battles for Stalingrad]. Stalingrad, Stalingradskoe knizhnoe izdatelstvo, 1961. $186 \mathrm{p}$.

3. General'naja shema Giprorechtransa NKRF o razvitii Stalingradskogo rechnogo porta (zapiski i chertezhi). 1944 g. [General Scheme of Development of the Stalingrad River-Boat Station (Notes and Drawings). The Scheme Was Produced by the Giprorechtrans of the People's Commissariat for River Fleet. 1944]. Gosudarstvennyj arhiv Volgogradskoj oblasti (dalee - GAVO) [State Archive of Volgograd Region], f. 557, inv. 19, d. 10.

4. Godovoj otchet ob jekspluatacionnoj dejatel'nosti NVRP za 1943 g. [Annual Report on the Lower Volga Steamship Line Operations in 1943]. $R G A E$ [Russian State Archive of Economy], f. 9469, inv. 6 , d. 47.

5. Godovoj otchet ob jekspluatacionnoj dejatel'nosti NVRP za $1945 \mathrm{~g}$. [Annual Report on the Lower Volga Steamship Line Operations in 1945]. RGAE [Russian State Archive of Economy], f. 9469, inv. 6, d. 98.

6. Godovoj otchet UNVRP za 1940 g. [Annual Report of the Lower Volga Steamship Line for 1940]. $R G A E$ [Russian State Archive of Economy], f. 1562, inv. $11, \mathrm{~d} .1025$. 
7. Gomanenko O.A. Navigacija 1943 goda: bitva za Volgu prodolzhaetsja [The Navigation of 1943: The Battle for the Volga Goes On]. Vestnik Volgogradskogo gosudarstvennogo universiteta. Seriya 4. Istoriya. Regionovedenie. Mezhdunarodnye otnosheniya [Science Journal of Volgograd State University. History. Area Studies. International Relations], 2019, vol. 24, no. 3, pp. 115-125.

8. Gomanenko O. Nizhnevolzhskoe rechnoe parohodstvo v Velikoj Otechestvennoj vojne. 1940 $1945 \mathrm{gg}$. [Lower Volga River Steamship Line in the Great Patriotic War. 1940-1945]. Saarbrücken, LAP LAMBERT Academic Publishing, 2011.256 p.

9. Gomanenko O.A. Novye dannye o poterjah rechnogo flota $v$ hode Stalingradskoj bitvy [New Data on Losses of the River Fleet During the Battle of Stalingrad]. Strezhen': nauch. ezhegodnik [Annual "Strezhen"]. Iss. 3. Volgograd, Izd-vo VolGU, 2003, pp. 293-321.

10. Doklad direktora Krasnoarmejskogo sudostroitel'nogo i sudoremontnogo zavoda g. Stalingrada. 1942 g. [Report of the Director of the Krasnoarmeisky Ship-Building and Ship-Repairing Factory of Stalingrad. 1942]. GAVO [State Archive of Volgograd Region], f. 5513, inv. 2, d. 3, 1. 7-15.

11. Kontrol'nye cifry raboty NVRP na $1937 \mathrm{~g}$. [Check Figures of the Lower Volga Steamship Line for 1937]. Gosudarstvennyj arhiv Astrahanskoj oblasti (dalee-GAAO) [State Archive of Astrakhan Region], f. 2345, inv. 1, d. 232.

12. Kratkoe opisanie NVRP i Stalingradskogo rechnogo porta za $1940 \mathrm{~g}$. [Short Review of the Lower Volga Steamship Line and Stalingrad River Port in 1940]. GAVO [State Archive of Volgograd Region], f. 557 , inv. 19 , d. 1 .

13. Material dlja sekretarja OK VKP(b) t. A.S. Chujanova, predsedatelja Ispolkoma Stalingradskogo oblsoveta deputatov trudjashhihsja t. I.F. Zimenkova, sekretarja GK VKP(b) t. I.A. Piksina ot Upolnomochennogo Gosplana pri SNK SSSR po Stalingradskoj oblasti t. Korotkova «Ob itogah vosstanovlenija g. Stalingrada za dva goda (aprel' 1943 g. - aprel' 1945 g.)» [Materials from the State Planning Commission Plenipotentiary Korotkov for Secretary of the Stalingrad Oblast Party Committee A.S. Chuyanov, Chairman of the Stalingrad Oblast Executive Committee I.F. Zimenkov, and Secretary of the Stalingrad Party Committee I.A. Piksin "On the Results of the Stalingrad Restoration Program for Two Years (April 1943 - April 1945)"]. GAVO [State Archive of Volgograd Region], f. R-686, inv. 20, d. 56.

14. Protokol № 24 zakrytogo partsobranija partorganizacii Stalingradskogo sudoremontnogo zavoda «Ob itogah navigacii 1942 g.». 19 dekabrja 1942 g. [Proceedings No. 24 of the Secret Meeting of the Party Organization of the Stalingrad Ship Repairing
Factory "On the Results of the 1942 Navigation". 19 December 1942]. Tsentr dokumentacii novejshej istorii Volgogradskoj oblasti (dalee - TsDNIVO) [Center for Documentation of the Modern History of Volgograd Region], f. 113, inv. 14, d. 165.

15. Svedenija dlja zam. predsedatelja SNK t. M.Z. Saburova ot zam. predsedatelja Gosplana t. Zelenovskogo ob jevakuacii Krasnoarmejskogo sudoremontnogo zavoda. 17 sentjabrja 1942 g. [Information for Deputy Chairman of the Council of People's Commissars of the Soviet Union M.Z. Saburov from Deputy Chairman of the State Planning Commission Zelenovsky on the Evacuation of the Krasnoarmeisky Ship-Repairing Factory. 17 September 1942]. RGAE [Russian State Archive of Economy], f. 4372 , inv. 42 , d. 847.

16. Svodnyj otchet po uchetu ushherba, prichinennogo nemecko-fashistskimi zahvatchikami i ih soobshhnikami, hozjajstvu NKRF SSSR. 1944 g. [The Summary Report on Accounting of the Damage Caused by Fascist Aggressors and Their Accomplices, to Economy of the Lower Volga Steamship Line of the USSR. 1944]. Gosudarstvennyj arhiv Rossijskoj Federacii [State Archive of the Russian Federation], f. 7021 , inv. 2, d. 356 .

17. Spisok nachal'nika tehnicheskogo otdela NKRF t. Leont'eva s perechnem jevakuirovannyh predprijatij NKRF. 3 maja 1943 g. [A List of the Evacuated Facilities of the Lower Volga Steamship Line Made Up by Head of the Technical Section of the Lower Volga Steamship Line Leontyev. 3 May 1943]. $R G A E$ [Russian State Archive of Economy], f. 4372, inv. 43, d. 775.

18. Spravka nachal'nika NVRP t. Kochenina «O vosstanovlenii i podgotovki $\mathrm{k}$ navigacii $1943 \mathrm{~g}$. hozjajstva NVRP». 2 fevralja 1943 g. [Memorandum by Head of the Lower Volga Steamship Line Kochenin "On Restoration of the Lower Volga Steamship Line Facilities and Their Preparation for the 1943 Navigation". February 2, 1943]. TsDNIVO [Center for Documentation of the Modern History of Volgograd Region], f. 11418, inv. 1, d. 31.

19. Spravka o sovremennom sostojanii Astrahanskogo rechnogo porta. 1938 g. [Memorandum on the Current Condition of the Astrakhan River-Boat Station. 1938]. GAAO [State Archive of Astrakhan Region], f. 2348, inv. 1, d. 99.

20. Spravka sekretarju Stalingradskogo GK VKP(b) t. I.A. Piksinu ot nachal'nika Stalingradskogo rechnogo porta t. Maturina «O podgotovke $\mathrm{k}$ navigacii 1943 g. i vosstanovlenii hozjajstva Stalingradskogo rechnogo porta». 29 marta $1943 \mathrm{~g}$. [Memorandum by Head of the Stalingrad River-Boat Station Maturin to Secretary of the Stalingrad City Party Committee I.A. Piksin "On Preparation for the 1943 Navigation and Restoration of the Stalingrad River-Boat Station". 
29 March 1943]. TsDNIVO [Center for Documentation of the Modern History of Volgograd Region], f. 71, inv. 2, d. 125, 1. 29.

21. Spravka sekretarju Stalingradskogo OK VKP(b) t. A.S. Chujanovu ot sekretarja OK VKP(b) po transportu t. I. Sidorova «O stepeni razrushenija zheleznodorozhnogo i vodnogo transporta i meroprijatijah po vosstanovleniju». Sentjabr' 1943 g. [Memorandum by Secretary for Transport of the Stalingrad Oblast Committee of the Communist Party I. Sidorov to Secretary of the Stalingrad Oblast Committee of the Communist Party A.S. Chuyanov "On the Amount of Damage of Railway and Water Transport and on the Measures for Their Restoration". September 1943]. TsDNIVO [Center for Documentation of the Modern History of Volgograd Region], f. 71, inv. 2 , d. 76 .

22. Spravka Upolnomochennomu komissii partijnogo kontrolja pri CK VKP(b) po Stalingradskoj oblasti t. I.A. Jagodkinu ot nachal'nika NVRP t. Kochenina i nachal'nika politotdela NVRP t. Shirmanova «O rabote NVRP v uslovijah fronta $v$
1942 g.». 7 fevralja 1943 g. [Memorandum by Head of the Lower Volga Steamship Line Kochenin and Head of the Political Section of the Lower Volga Steamship Line Shirmanov to Plenipotentiary of the Party Control Commission I.A. Yagodkin "On Operations of the Lower Volga Steamship Line in the Front Conditions of 1942". 7 February 1943]. TsDNIVO [Center for Documentation of the Modern History of Volgograd Region], f. 11418, inv. 1, d. 27.

23. Spravki otdela i sekretarej partorganizacij, nachal'nikov rechnogo porta i zheleznoj dorogi o vosstanovlenii i rabote zheleznodorozhnogo i rechnogo transporta, o sostojanii partijnopoliticheskoj raboty. Fevral' - avgust 1943 g. [Memoranda by the Department and Secretaries of Party Organizations and Heads of the River ShipStation and the Railway Line on Restoration and Operations of Railway and Water Transport and on Party and Political Propaganda. February - August 1943]. TsDNIVO [Center for Documentation of the Modern History of Volgograd Region], f. 71, inv. 2, d. 125 .

\section{Information About the Author}

Olesya A. Gomanenko, Candidate of Sciences (History), Associate Professor, Department of Sociology and Social Technologies, Volgograd State University, Prosp. Universitetsky, 100, 400062 Volgograd, Russian Federation, gomanenko@volsu.ru, gomanenko.olesya@mail.ru, https://orcid.org/0000-0001-9178-1145

\section{Информация об авторе}

Олеся Александровна Гоманенко, кандидат исторических наук, доцент кафедры социологии и социальных технологий, Волгоградский государственный университет, просп. Университетский, 100, 400062 г. Волгоград, Российская Федерация, gomanenko@volsu.ru, gomanenko.olesya@mail.ru, https://orcid.org/0000-0001-9178-1145 